\title{
CURRENT STATUS OF RESIDENCY TRAINING IN LAPAROSCOPIC SURGERY IN BRAZIL: A CRITICAL REVIEW
}

\author{
Situação atual do treinamento de médicos residentes em videocirurgia no Brasil: uma análise crítica
}

Miguel Prestes NÁCUL르, Leandro Totti CAVAZZOLA', Marco Cezário de MELO²

From the ${ }^{1}$ Programa de Pós-Graduação em Ciências Cirúrgicas, Faculdade de Medicina, Universidade Federal do Rio Grande do Sul Porto Alegre, RS, e ${ }^{2}$ Equipe DIGEST ('PostGraduate Program in Surgical Sciences, Faculty of Medicine, Federal University of Rio Grande do Sul, Porto Alegre, RS, and ${ }^{2}$ DIGEST Team, Recife, PE), Brazil
ABSTRACT - Introduction: The surgeon's formation process has changed in recent decades. The increase in medical schools, new specialties and modern technologies induce an overhaul of medical education. Medical residency in surgery has established itself as a key step in the formation of the surgeon, and represents the ideal and natural way for teaching laparoscopy. However, the introduction of laparoscopic surgery in the medical residency programs in surgical specialties is insufficient, creating the need for additional training after its termination. Objective: To review the surgical teaching ways used in services that published their results. Methods: Survey of relevant publications in books, internet and databases in PubMed, Lilacs and Scielo through july 2014 using the headings: laparoscopy; simulation; education, medical; learning; internship and residency. Results: The training method for medical residency in surgery focused on surgical procedures in patients under supervision, has proven successful in the era of open surgery. However, conceptually turns as a process of experimentation in humans. Psychomotor learning must not be developed directly to the patient. Training in laparoscopic surgery requires the acquisition of psychomotor skills through training conducted initially with surgical simulation. Platforms based teaching problem solving as the Fundamentals of Laparoscopic Surgery, developed by the American Society of Gastrointestinal Endoscopic Surgery and the Laparoscopic Surgical Skills proposed by the European Society of Endoscopic Surgery has been widely used both for education and for the accreditation of surgeons worldwide. Conclusion: The establishment of a more appropriate pedagogical process for teaching laparoscopic surgery in the medical residency programs is mandatory in order to give a solid surgical education and to determine a structured and safe professional activity.
HEADINGS - Laparoscopy. Education Medical. Learning. Internship and Residency.
RESUMO - Introdução: A formação do cirurgião geral vem se modificando nas últimas décadas. O aumento das escolas médicas, as novas especialidades e as modernas tecnologias induzem à reformulação do ensino médico. A residência médica em cirurgia estabeleceu-se como etapa fundamental na formação do cirurgião e surge como a forma ideal e natural para o ensino da videocirurgia. No entanto, a introdução da videocirurgia nos programas de residência médica nas diversas especialidades cirúrgicas é insuficiente, gerando a necessidade de treinamento complementar após o seu término. Objetivo: Rever a situação de ensino da videocirurgia em serviços que publicaram seus métodos. Método: Revisão de conteúdo publicado em livros e na internet considerados relevantes, além de pesquisa nas bases de dados PubMed, Lilacs e Scielo até julho 2014 com os descritores: videocirurgia; simulação; educação médica; aprendizagem; treinamento em cirurgia. Resultado: $O$ método de treinamento em programas de residência médica em cirurgia, focado na realização de procedimentos cirúrgicos sob supervisão em pacientes, comprovou sua eficiência na era da cirurgia aberta. No entanto, configura conceitualmente um processo de experimentação em seres humanos. O aprendizado psicomotor não deve e não pode ser desenvolvido diretamente no paciente. A formação em videocirurgia requer a aquisição de habilidades psicomotoras únicas, através de treinamento realizado inicialmente por simulação cirúrgica. Plataformas de ensino baseadas na solução de problemas como o Fundamentals of Laparoscopic Surgery, desenvolvido pela Sociedade Americana de Cirurgia Endoscópica Gastrointestinal e o Laparoscopic Surgical Skills proposto pela Sociedade Europeia de Cirurgia Endoscópica são exemplos que têm sido amplamente utilizados tanto para o ensino como para a acreditação de cirurgiões em todo o mundo. Conclusão: É necessário o estabelecimento de um processo pedagógico mais adequado para o ensino da videocirurgia nas residências médicas no sentido de conferir base educacional sólida, determinando atividade profissional bem estruturada e segura.
DESCRTORES - NeoLaparoscopia. Educação médica. Aprendizagem. Internato e Residência.
"No more debating the validity of this pioneering technique (laparoscopic surgery), but yes, we are concerned with how to educate and train residents and surgeons." 27

Carol Scott-Conner, M. D. Editor-in-Chief

Surgical Laparoscopy Endoscopy \& Percutaneous Techniques 
permitted the expansion of technical possibilities, from diagnosis to therapy. The great explosion of videosurgery occurred through the development of microcamera and its coupling to the laparoscopic optics. In 1987, the laparoscopic Philippe Mouret in Lyon, France, established the conditions that favored the development of laparoscopic surgery and its rapid and spectacular expansion, featuring the greatest advance in $20^{\text {th }}$ century surgery ${ }^{16}$.

The revolution generated by laparoscopic cholecystectomy determined that this approach will be used in a variety of procedures. Laparoscopy was gradually introduced in the treatment of different diseases, achieving the status of "gold standard therapeutic" for several situations ${ }^{17}$. The advent of surgical procedures performed by laparoscopy reached not only the General Surgery and the Digestive System Surgery, as well as other surgical specialties with important projection ${ }^{20}$. Technological development impact on quality and on increasing possibility of new equipments and instruments, associated with technical development of the surgeons, determined very rapidly changing in the method, which has become highly specialized, requiring specific training ${ }^{20}$.

The formation of the general surgeon has changed significantly in recent decades. The increase in the number of medical schools, the creation of new surgical specialties, the adoption of new technologies, as videosurgery, raised the obvious need for special training in this area, with significant change in general surgery teaching process ${ }^{29}$.

The objective of this article is to review the published methods used to update the educational situation of the videosurgery training program realized by several surgical services.

METHOD

Scientific articles were selected in English or Portuguese in the databases PubMed, Lilacs and Scielo until July 2014, using the headings: laparoscopy; simulation; medical education; learning; internship and residency. In addition, content published in books, not indexed publications and government decrees available on the internet and deemed relevant by the authors, were also used.

\section{RESULT}

\section{Teaching in surgery}

The training in surgery should be developed in stages, gradually and progressively in complex procedures, requiring sufficient training time, so very long ${ }^{19}$. Should be performed in accredited service for such activity, with significant surgical volume and under preceptorship supervision. Conceptually, preceptor is an experienced professional who assists in the formation of apprentices ${ }^{24}$. The teacher has the function of providing situations and to stimulate the learners to build their knowledge, stimulating them to make their own discoveries. His experience should be taken into consideration, but should not be seen as absolute knowledge owner ${ }^{24}$.

First big name on surgery in the era of modern medicine, William Stewart Halsted, established new supervised methods with effective training, which he called "residence" because doctors actually lived in the hospital. It was in 1889, and the pioneering idea was implemented through the first professional training program in hospital at the John Hopkins Hospital in Baltimore, Maryland, USA ${ }^{10}$. Since then, surgeons have been trained on the same training process. The medical residency in Brazil was created following the same program design developed at the beginning of the century in USA ${ }^{11}$. Professor Mariano de Andrade at the State Servers Hospital in
Rio de Janeiro and Professor Alípio Correa Neto at the Clinical Hospital in São Paulo, devised the first programs in surgery in Brazil, but still without the methodization and regulations that only happened posteriorly ${ }^{11}$. On September 5, 1977, being President of the Republic of Brazil General Ernesto Geisel sanctioned the creation of the Medical Residency which was defined as "graduate teaching modality for doctors in the form of specialization course characterized by in-service training, working in health institutions, university or not, under the guidance of medical professionals of high ethical qualification and professionalism ${ }^{3}$. In 1987 the State Commissions were created, formed by the general coordinators of the various residency programs in the state; also, all hospitals with residency program should have its own Medical Residency Committee (Coreme) consisting of coordinators of all programs offered by the institution ${ }^{25}$. Currently, residency obeys its own laws and regulations and can only receive this designation the training program accredited by the Ministry of Education of Brazil. The residency gives the doctor after its completion, the certificate of expert in the specialty ${ }^{3}$.

With the fundamental base in-service training, medical residency is considered the most important learning technique after graduation and is the best training method for surgeons ${ }^{25,29}$. It must be developed in the scenario where the teaching-learning process is supported in same amount by medical assistance, both in balance. Resident physician must not only develop technical skills, but also be responsible for behavior practices, shaped by ethics and the spirit of cooperation that should guide medical practice. A good program in General Surgery aims to provide comprehensive training so that, at the end, the future surgeon will be qualified to exercise his specialty as a professional able to offer to the society, service with maximum quality and humanity, developing skills in the affective domain, as improvement of judgments and moral precepts, which are basic requirements for integration into the labor market with full autonomy ${ }^{12,24}$.

\section{Training in laparoscopic surgery in Brazil}

The emergence of modern technologies and new ways of performing surgical procedures impose to surgeon training in these procedures, generating additional training period that was not covered by existing models. Among the new technologies, videosurgery emerges as a technique to be taught and learned in terms of importance in the current context of the surgical specialties ${ }^{29}$.

In order to perform the laparoscopic surgery is needed well-structured learning process, relatively complex ${ }^{19}$. There is now in Brazil great deficit in education and training in laparoscopic surgery in different surgical specialties, resulting in the slow evolution of art in country ${ }^{19}$. This may be charged to several factors: 1) amazing misinformation about the method even for specialists; 2 ) professional context of socio-economic deterioration of the doctor discouraged to invest in updating; 3) high cost of equipment, often funded by the own physician with incomes got through medical security plans or SUS payments in Brazil, which do not remunerate enough to enable large investments; 4) lack of organizational and structural "know-how" on the method, which greatly complicates the initiation and professional development; 5) self-sufficiency and conservatism of surgeons with old maintenance "surgical dogmas"; 6) qualitative and quantitative deficiency courses and residency programs; 7) specific technical aspects of learning that determine educational difficulties of complex resolution; 8) disconnection of the evolutionary process of the method of surgical specialties who repeat the difficulties already overcome by the others; 9) lack of development of "surgical schools" aimed at laparoscopic surgery.

The teaching of laparoscopic surgery in Brazil has not been able to form well-trained professional to perform procedures safely by this method. The main reason for this 
reality comes from training based on intensive courses which focus their pedagogical model in the development of motor skills in the shortest possible time. This methodology fails to give the knowledge of different environment domain and technologically complex, which is as important as the surgical technique domain. Also, do not give enough surgical experience to enable the surgeon to start his activity safely. Technically limited and poorly adapted to video-surgical environment, the surgeon finds it difficult to deal with complex situations as evidenced by long learning curves and conversion rate above the expected. These facts bring harm to patients, surgeons and the concept of the method to the scientific community and the public in general ${ }^{19,20,29}$.

The central question is: how to determine efficient and comprehensive development process of laparoscopic surgery in our environment with the ultimate goal of disseminating knowledge about the method, keeping the best standard of surgical quality, promoting effective training and professional activity better structured, updated and secure?

\section{Laparoscopic surgery and residency in surgery}

Medical surgical residency was established as a key step in the formation of the surgeon. In the era of laparoscopic surgery, presents the ideal and natural way to teach this technique. However, the residency programs in the various surgical specialties have failed to offer (when they offer) solid background in videosurgery ${ }^{19}$. This fact is the lack of specific curriculum that includes the steps required for effective training in laparoscopic surgery. Moreover, the volume and preceptors in videosurgery procedures also cooperate to this reality ${ }^{19}$

The method of training in residency programs in surgery focused on surgical procedures under supervision has proven successful in the era of open surgery ${ }^{19,29}$. This method does not presuppose surgical simulation, so, not setting up a process of experimentation on human beings for the development of surgical skills, due it is accomplished by performing surgical procedures in patients ${ }^{12}$. In the era of minimally invasive procedures, in particular, performed by laparoscopic surgery, psychomotor learning should not and cannot be developed directly on the patient. Must be accomplished by surgical simulation, in organic, inorganic or virtual models, that must precede the training phase in humans. The surgeon has to adapt in advance to a completely different working environment than that in which he is used when performing open procedures ${ }^{18}$.

\section{Training in videosurgery}

In 1956, Benjamin Bloom, educational psychologist at the University of Chicago, shared educational goals of learning in three domains: the cognitive, the affective and the psicomotor ${ }^{14}$. On learning videosurgery, undoubtedly, the area most in need of training and development is the psicomotor domain ${ }^{18}$.

Motor learning uses the mechanisms and processes underlying motor practice behavior changes, passing since the point where individual does not dominate particular skill until the run proficiently as a result of the practice period - a situation also known as learning curve ${ }^{14}$. This curve reflects the process of learning by doing. The basic idea is that, to the extent that people repeat a task, the time that they take to make it gradually decreases. Learning curve can then be defined as the representative graphic expression of the incorporation of a new period of knowledge ${ }^{14}$. In practice have been used as criteria for defining learning curve in surgery the surgical time and the number of procedures that an average surgeon needs to be able to perform the procedure with a reasonable result ${ }^{14}$.

The motor learning involves the use of innate individual skills, stable and permanent. Few in number, capabilities underpin the performance of many skills. Skills are those developed and modified with practice. In large numbers depend on several subsets of different capabilities ${ }^{19}$. When conducting training in laparoscopic surgery is a clear need of learning or relearning some motor skills, a fundamental factor in the acquisition of surgical proficiency ${ }^{18}$. Starting movements monitored by two-dimensional view, it can be reached a new order with consistency and automation. Initial stage of motor learning is followed by middle phase of greater consistency, lower incidence of error, small attention demand and coming to automation plateau, ie stabilization ${ }^{18}$. The learning process should be done in stages, initially being obviously necessary know and handle the equipment and instruments of laparoscopic surgery. Furthermore, it should be considered that in the teaching of video-specific features exist in the motor learning process as a radical change in the perception of environment, indirect image, camera use, two-dimensionality, and use of long devices placed in fixed-point. In addition, the instruments tend to take the opposite direction of the movement and there is a clear loss of tactile perception. It is therefore crucial to undergo some psychomotor adaptations related to the vision and the environment of laparoscopic surgery, which can be facilitated by various types of training. It should be performed in an environment that represents the video-surgical one, which is entirely different from experienced by open/conventional surgery ${ }^{18}$.

Recent reports from the World Health Organization on safety and quality performance in surgery, emphasize the urgent need to improve the training, assessment and accreditation for technologically dependent surgical procedures, as in videosurgery ${ }^{4}$. The traditional surgical education training model in residence with the teachinglearning tutorial action centered on the teacher direct acting on the student, was inadequate or limited to train surgeons in laparoscopic surgery, especially in the early stages of training ${ }^{7}$. Intuitively, concepts related to the classical training in surgery - established for over a hundred years - were applied to the teaching of laparoscopic surgery. The adaptation of unique psychomotor skills is not automatically transferred from the previous training in open surgery ${ }^{7}$, so it is necessary for the acquisition of new skills, new learning surgical tools ${ }^{1,28}$. The videosurgery rescued medical simulation for teaching surgery. Initially using simple simulators, then by experimental surgery in animal models and, more recently, incorporating realistic simulation and virtual reality, simulation has become the central stage and fundamental basis of the process of teaching and learning due to its highest potential to mimic real situations. Added to specific theoretical knowledge, training should be done in a planned, progressive complexity of procedures and never initially in patient ${ }^{18}$.

Currently, it is widely recognized that the first part of training for laparoscopic surgery should be performed outside the operating room, for training in simulators that mimic the video-surgical environment. After properly adapted to this new environment, training continues in the clinic, by performing video procedures in humans, under the supervision ${ }^{4}$.

Factors such as the reduction of time available to train and supervise surgeons in training, the inadequacy of surgeon accreditation based only by the number of performed procedures, among other medical-legal and socio-economic connotation, led to the paradigm shift in the surgical training ${ }^{26}$. Medical simulation is at the center of the paradigm change in teaching surgery ${ }^{26}$. The training in surgery should move from a "Halstedian" model ("see one, do one, teach one"), to a model determined by simulation ("do many, mentored always") ${ }^{26}$

New technologies determine new teaching and learning methods often conceptually different from those used 
previously. The advent of surgical procedures performed by single incision or single portals, surgeries by natural orifices ("Natural Orifice Translumenal Endoscopic Surgery" - NOTES) and robotics bring important challenges in teaching these techniques that sooner or later will also be expressed in training programs in medical residency in surgery ${ }^{5}$.

\section{Simulation}

The modern concept of simulation is assigned to the American engineer Edwin A. Link, responsible for the development of the first flight simulator that takes its name, the "Link Trainer". Already the first dummy used in simulation in the medical field was developed in 1960 by the Norwegian Asmund Laerdal for cardiopulmonary resuscitation, named "Annie". At Harvard University, also in 1960, Abrahanson Denson and built the model "Yes one", to reproduce the heart and lung sounds. From that date, great impetus was given to other models of mannequins supported by high technology were created, like those for delivery care, laparoscopic surgery and others ${ }^{8}$.

Conceptually, simulation technique to replace or expand real experiences with guided experiences, often is engaged in evoking or replicating substantial aspects of the real world totally in an interactive way ${ }^{6}$. The simulator is device that mimics an actual patient or body part capable of interacting with the student ${ }^{6}$. It may also be defined as a device that reproduces part of the system or process ${ }^{6}$.

The science of simulation not only includes the simulator technology, but new curricula, objectives, evaluation methods and requirements based on criteria. The improvement of medical practice through simulation increases the multidimensional learning experience. The personal subjective evaluation is replaced by the evaluation process based on uniform criteria and objectives with the possibility of being re-evaluated at every step. So the whole educational process can and should be based on objective proficiency criteria $^{26}$. In addition to reducing the learning curve, the simulation has proven action in assessing the surgeon's prior experience in laparoscopic surgery, quantifying at different levels of education according to the surgeon's ability to operate different degrees of complexities ${ }^{14,18}$.

The simulation training method is used mainly in risk activities, with the aim of increasing the safety of processes. In health care, however, its application is relatively recent compared to aviation, for example. The specific simulation to health care is an attempt to reproduce the essential aspects of the clinical setting so that when a similar scenario occurs in real clinical context, the situation can be managed easily and with greater possibility of been successful23. The use of realistic simulation in education of health professionals allows students to practice the skills necessary environment that allows mistakes and professional growth without risking patient safety. Knowledge is constructed from scheduled, representing situations of professional practice reality, simulated by prototypes, patient-actors in protected and controlled environment. The method allows control of external factors, standardization of the problems presented by patients and positive feedback of information for students, which facilitates the evaluation of performance and clinical skills ${ }^{24}$. The realistic simulation expanded rapidly around the world and today, the latest equipment perfectly reproduces the various scenarios and behaviors of the human body ${ }^{9}$

Simulation as a pedagogical strategy based on problem solving

Surgical simulation conceptually works with situations that seek to replicate the reality of a surgical procedure in a patient using approach based on problem solving. Learning process based on problem solving has been globally recognized as a valuable tool in the training of health professionals with advantages over the teaching traditional method ${ }^{2,21}$

There are several dedicated pedagogical proposals that use realistic simulation, as substantiation and questioning as a method. In laparoscopic surgery, the teaching-learning process has evolved to the use of curricular platforms with more wide methods ${ }^{21}$. The transfer of skills developed by training in simulators for surgical practice is most effective when it is not limited only to the simulator, but includes in its curriculum of clinical knowledge tools, preferably using interactive multimedia learning material ${ }^{22}$.

In Europe, "Laparoscopic Surgical Skills Programme" (LSS) is a project of the European Society of Endoscopic Surgery, newly developed, validated and implemented as multi-level education curriculum and training platform in videosurgery ${ }^{15}$. The LSS goes beyond basic skills. It is the first program that combines assessment based on performance criteria in simulation performance indicators in the surgical field. Within each stage of the LSS, the evaluation incorporates sequence of tests to evaluate the surgeon's proficiency in cognitive abilities, surgical technical skills and judgment. To this end, material and computerized tests are combined with various forms of simulation, analysis based on scenarios and performance in clinical evaluation ${ }^{4,15}$

In North America, the most widely used and approved today for training in laparoscopic surgery is the program "Fundamentals in Laparoscopic Surgery" (FLS) developed by leaders of the American Society for Gastrointestinal Endoscopic Surgery and also approved by the American College of Surgeons ${ }^{13,21}$. Developed between 1997 and 2004, the FLS is an educational assessment module designed to teach the fundamental knowledge, judgment and technical skills needed in laparoscopic surgery with emphasis on laparoscopy. It consists of cognitive learning, practical training ("hands-on") skills and a supervised examination that provides surgeons in training the opportunity to assess and document their skills ${ }^{13}$. The FLS uses combination of various types of training methods, computer-based learning modules in theoretical content and sequence of exercises in simulator type "black box" for the development of skills and performance evaluation. Medical residents in surgery of the first year are now required to participate in the FLS program in North America, an initiative to create minimum standards for professional practice ${ }^{13}$.

In Brazil urges the creation of more training centers, better-equipped both from a human point of view as a structural, permanent, with longer duration teaching projects, consistent from a pedagogical point of view, with greater emphasis on organizational guidance and support tutorial. The development of "forming schools of video-surgeons" should be encouraged.

The formation of pedagogical knowledge seems to be essential. Not enough to be a good and well-trained surgeon to perform effective teaching activities to the student. You must learn to use appropriate teaching techniques within wellstructured training and evaluation projects. In this sense, the teacher must understand aspects related to motor learning, surgical simulation, virtual reality and distance learning by telemedicine, that are increasingly incorporated into the teaching of laparoscopic surgery.

The videosurgery recued medical experimentation as a key step in the surgeon's training to carry out new techniques. The simulation is an integral part of the teaching-learning process, but is only one stage of the curriculum that needs to be built and adapted to different populations of surgeons in training and the reality of various countries and regions worldwide. Training should include a mix of training methods through the use of multimedia platforms, simulators linked to performance assessment tools.

As it has evolved, the formation of the general surgeon performed during residency is still focused on the exchange 
of experiences in the observance of models and replication attitudes and behaviors acquired in the implementation or monitoring of different surgical procedures. Currently, the main training focus should be on laparoscopic surgery and not open surgery. In open surgery there is natural environment from the point of view of the psychomotor domain. In laparoscopic surgery, it is necessary adaptation to the new surgical environment, showing all the complex facets and interfaces that integrate the procedure determined by the work space distinct from the usual perceptions. Therefore, the development of surgical skills and adaptation to laparoscopic environment cannot be done initially in the patient. In this situation would be characterized experimentation in humans.

However, despite the evolution, the formation of the general surgeon is still focused on the exchange of experiences in the observance of models and replication attitudes and behaviors. Theoretical knowledge and evidencebased medicine can be learned and reproduced in textbooks, but nothing, not even the fantastic computer simulations currently available and virtual reality, the surgeon can replace the experience of the operative field, and it is only gained in the implementation or monitoring of the various interventions.

We are still far from the American or European standard with regard to the training of our residents in laparoscopic surgery. Considering the amount and insufficient quality courses and training centers in laparoscopic surgery, we are really facing a real dilemma, a serious problem. The resolution is, no doubt, the greater integration of the teaching of laparoscopic surgery in residency programs.

For this, we need the development of preceptorship and creating structure in services that work with education in surgery. It is now up to medical schools and services that offer medical residency adapt to this need not only of medical practitioners in training, but mainly the population that wants, and deserves, to be submitted to surgical procedures less and less invasive. The ultimate goal is to provide solid educational base, determining activities well structured and safe. To generate a prepared professional with unlimited potential, in continuous evolution and with the best standard of surgical quality should be the result of the entire educational effort.

\section{CONCLUSION}

The spread and evolution of laparoscopic surgery involves vigorous investment in technology, education and qualification. This process should start during medical graduation. The use of a more efficient teaching process, using modern concepts in line with the global trend and in line with the widespread use of laparoscopic surgery in surgical specialties, becomes highly necessary.

\section{REFERENCES}

1. Bashankaev B, Baido S, Wexner S. Review of available methods of simulation training to facilitate surgical education. Surg Endosc 2011; 25(1):28-35.

2. Berbel NAN. Metodologia da Problematização: uma alternativa metodológica apropriada para o Ensino Superior. Semina: Cio Soc/ Hum Londrina1995; 16(2):9-19.
3. Brasil. Ministério da Educação e Cultura. Residências em Saúde. Residência Médica. Decreto no 80.281, de 05 de setembro de 1977. Ministério da Educação - Disponível em http://portal.mec.gov.br/ index.php?option =com_content $\&$ view $=$ article\&id $=13087$ : decret os-residencia-medica\&catid=247\&Itemid=164. Acesso em 19 de setembro de 2014

4. Buzink S, Fingerhut A, Hanna G, Jakimowicz J, Radonak J, Soltes M. Laparoscopic Surgical Skills programme: preliminary evaluation of Grade I Level 1 courses by trainees. Wideochir Inne Tech Malo Inwazyjne 2012; 7(3):188-92.

5. Cavazzola L. Laparoendoscopic Single Site Surgery (LESS) - Is it a bridge to Natural Orifice Translumenal Endoscopic Surgery (NOTES) or the final evolution of minimally invasive surgery? Rev Bras Videocir 2008; 1(3):93-4.

6. Cooper JB, Taqueti VR. A brief history of the development of mannequin simulators for clinical education and training. Qual Saf Health Care 2004; 13(1):11-8.

7. Figert PL, Park AE, Schwartz RW, Witzke DB. Transfer of training in acquiring laparoscopic skills. J Am Coll Surg 2001; 193(5):533-7.

8. Gaba DM. The future vision of simulation in healthcare. Simul Healthc. 2007; 2(2):126-35.

9. Godson NR, Goodman M, Wilson A. Evaluating student nurse learning in the clinical skills laboratory. Br J Nurs 2007; 16(15):942-5.

10. Harvey AM. The influence of William Stewart Halsted's concepts of surgical training. Johns Hopkins Med J 1981; 148(5):215-36.

11. Herbella FA, Del Grande JC, Dubecz A, Fuziy RA, Takassi GF. Evaluation of training and professional expectations of surgery residents. Rev Col Bras Cir 2011; 38(4):280-4.

12. HossneWS, De Freitas CB, Vieira S. Committees for Ethics in Research involving human subjects. J Int Bioethique 2008; 19(1-2):131-41.

13. Integrating advanced laparoscopy into surgical residency training. Society of American Gastrointestinal Endoscopic Surgeons (SAGES). Surg Endosc 1998; 12(4):374-6.

14. Kumar U, Gill IS. Learning curve in human laparoscopic surgery. Curr Urol Rep. 2006; 7(2):120-4

15. Laparoscopic Surgery Skills [Internet]. LSS Foundation 2014 [citado em 10 de julho 2014]. Disponível em: http://www.lss-surgical.eu/ nl/pages/home. Acesso em 19 de setembro de 2014.

16. Lau WY, Leow CK, Li AK. History of endoscopic and laparoscopic surgery. World J Surg 1997; 21(4):444-53.

17. Melo MAC. Diante de um ponto de não-retorno. Rev Bras Videocir 2003; 1(4): 124-7.

18. Melo MAC. Questões relacionadas à Aprendizagem Motora na Videocirurgia. Rev Bras Videocir 2007; 5 (2): 79-89.

19. Nácul MP. Aspectos Atuais do Ensino da Videocirurgia no Brasil Uma Análise Crítica (Editorial). Rev Bras Videocir 2004; 2(1):1-4.

20. Nácul MP. Conceitos e estado da arte da videoci $\neg$ rurgia. Rev Saúde UCPEL. 2007; 1(2):149-59.

21. Okrainec A, Fried GM, Soper NJ, Swanstrom LL. Trends and results of the first 5 years of Fundamentals of Laparoscopic Surgery (FLS) certification testing. Surg Endosc 2011; 25(4):1192-8

22. Pape-Koehler $C$, Heiss $M$, Immenroth $M$, Lefering $R$, Lindlohr $C$ Sauerland $S$, Toaspern J. Multimedia-based training on Internet platforms improves surgical performance: a randomized controlled trial. Surg Endosc 2013; 27(5):1737-47.

23. Sanino, GE. O uso da simulação em enfermagem no Curso Técnico de Enfermagem. J. Health Inform 2012; 4:148-51.

24. Santos EG , Bravo Neto GP, Ferreira RR, Goldwasser RS, Leher EM, Mannarino VL. Assessment of preceptorship in general surgery residency in the operating room, comparison between a teaching hospital and a non teaching hospital. Rev Col Bras Cir 2012; 39(6):547-52.

25. Santos EG. General surgery residency in Brasil - very far from real practice. Rev Col Bras Cir 2009; 36(3):271-6.

26. Satava RM. Emerging trends that herald the future of surgical simulation. Surg Clin North Am 2010; 90(3):623-33.

27. Scott-Conner CE, Anglin BL, Hall TJ, Muakkassa FF, Poole GV, Thompson AR, Wilton PB. The integration of laparoscopy into a surgical residency and implications for the training environment. Surg Endosc 1994; 8(9):1054-7.

28. Stefanidis D. Optimal Acquisition and Assessment of Proficiency on Simulators in Surgery. Surg Clin North Am 2010; 90(3):475-489.

29. Vieira OM. Escolha das especialidades: assunto em discussão. Rev. Col. Bras. Cir. 2007; 34(1):1-1. 